\title{
Glacier fluctuation using Satellite Data in Beas basin, 1972-2006, Himachal Pradesh, India
}

\author{
Shruti Dutta*, A L Ramanathan and Anurag Linda \\ Glacier Research Group, School of Environmental Sciences, Jawaharlal Nehru University, New Delhi, India. \\ ${ }^{*}$ Corresponding author. e-mail: sakshishruti@gmail.com
}

Glaciers are widely recognized as sensitive indicators for regional climate change. Very few studies have been conducted to investigate the long term deglaciation status in the Himalaya. In the present study, glaciers in the Beas basin, Himachal Pradesh, India were mapped by interpretation of various glaciomorphological features using the Landsat and IRS images. The mapping of 224 glaciers during the period 1972-2006 reveals that the glacier cover reduced from 419 to $371 \mathrm{~km}^{2}$, witnessing approximately $11.6 \%$ deglaciation in the Beas basin. A higher rate of retreat of the glaciers was observed during 1989-2006 as compared to the retreat during 1972-1989. Also, the loss has been more prominent in the glaciers with an areal extent of $2-5 \mathrm{~km}^{2}$. The number of glaciers increased from 224 to 236 due to fragmentation in this period. The average elevation of the ablation zone basin showed an upward shift from $3898 \mathrm{~m}$ (1972) to $4171 \mathrm{~m}$ (2006) which may be a consequence of a shift in Equilibrium Line Altitude (ELA) reflecting imbalance.

\section{Introduction}

The Indian Himalaya comprises of approximately 9600 glaciers (Raina and Srivastava 2008). The snow and ice melt water from these glaciers form a unique freshwater reservoir. Numerous perennial rivers such as Indus, Brahmaputra and to a modest level, the river Ganga, depend on the melt water, subsequently making these glaciers act as lifelines for millions of people (Immerzeel et al. 2010). Glaciers are now well recognized as the most reliable indicators of climate change (IPCC 2007), more particularly in the regions where there is an acute paucity in the availability of meteorological database. The dynamics of the Himalayan river flow is highly influenced by the seasonal and monsoonal precipitation as well as by snow and ice melt (Immerzeel et al. 2010). Thus, the monitoring of these glaciers is important to assess the overall reservoir health (Bhambri et al. 2011).
The remoteness and logistic constraints of the Himalayan glaciers pose hindrance in regular monitoring and collection of data through field methods. Remote sensing techniques involving multitemporal and multispectral satellite images are potentially valuable tools for the mapping, regular monitoring and systematic assessment of glacial extent.

Various studies conducted in the Himalayan region have elucidated the impact of temperature as a major controlling factor for glacial change (Berthier et al. 2007; Kulkarni et al. 2007, 2011; Wagnon et al. 2007; Bhambri et al. 2011). Recent study on 'Snow and Glacier' provides valuable informations on the long term monitoring of the snow cover for the Indian Himalaya from 1962 to 2007-2008. (Technical Report, SAC 2011). In this study, glacier inventories were prepared in the Indus, Ganga and Brahmaputra basins on 1:50,000 scale using satellite data of the period 2004-2007. Snow cover monitoring for the period 1997-2001

Keywords. Glaciers; Himalaya; Beas basin; remote sensing; deglaciation. 
has been carried out in the Beas basin (Kulkarni et al. 2011). Bhambri et al. (2011) used Corona and ASTER images of 1968 and 2006 to map the glaciers in the Bhagirathi and Saraswati/ Alaknanda basins of the Garhwal Himalaya. The study revealed that the glacier vacated an area of about $4.6 \pm 2.8 \%$ with the recession rates increasing more recently (1990-2006). The basin showed fragmentation which led to an increase in the number of glaciers from 82 (1968) to 88 (2006). Another study using the satellite data and field verifications concludes that a large part of the Tipra glacier (Alaknanda basin), showing one snout in 1987, has been detached from the main trunk and separated into the Tipra $\left(7.5 \mathrm{~km}^{2}\right)$ and Ratanban $\left(7.4 \mathrm{~km}^{2}\right)$ during $1962-2002$. Moreover, the surface area reduced by $18 \%$ and snout retreat was about $535 \mathrm{~m}$ with an average retreat of $13.4 \mathrm{ma}^{-1}$ (Mehta et al. 2011). A compilation of glacier inventory by Geological Survey of India (GSI) using aerial photographs and satellite images (Sangewar and Shukla 2009) is noteworthy. A study by Bhutiyani et al. (2009) indicates a significant decreasing trend in monsoon and annual precipitation during the study period 1866-2006. Another study (Bhutiyani et al. 2007) has confirmed that the northwestern Himalayan region has witnessed a rise of temperature by about $1.6^{\circ} \mathrm{C}$ in the last century. Some landmark studies using remote sensing data have been done to estimate the glacier retreat for 466 glaciers in Chenab, Parbati and Baspa basins (Kulkarni et al. 2007) showing an overall deglaciation of $21 \%$ during 1962-2001.

Few pioneering studies on the retreat of Parbati Glacier (Kulkarni et al. 2005) and retreat of glaciers in Parbati sub-basin (Kulkarni et al. 2007) have been carried out. However, the study accounts for only 88 glaciers out of 153 glaciers mapped
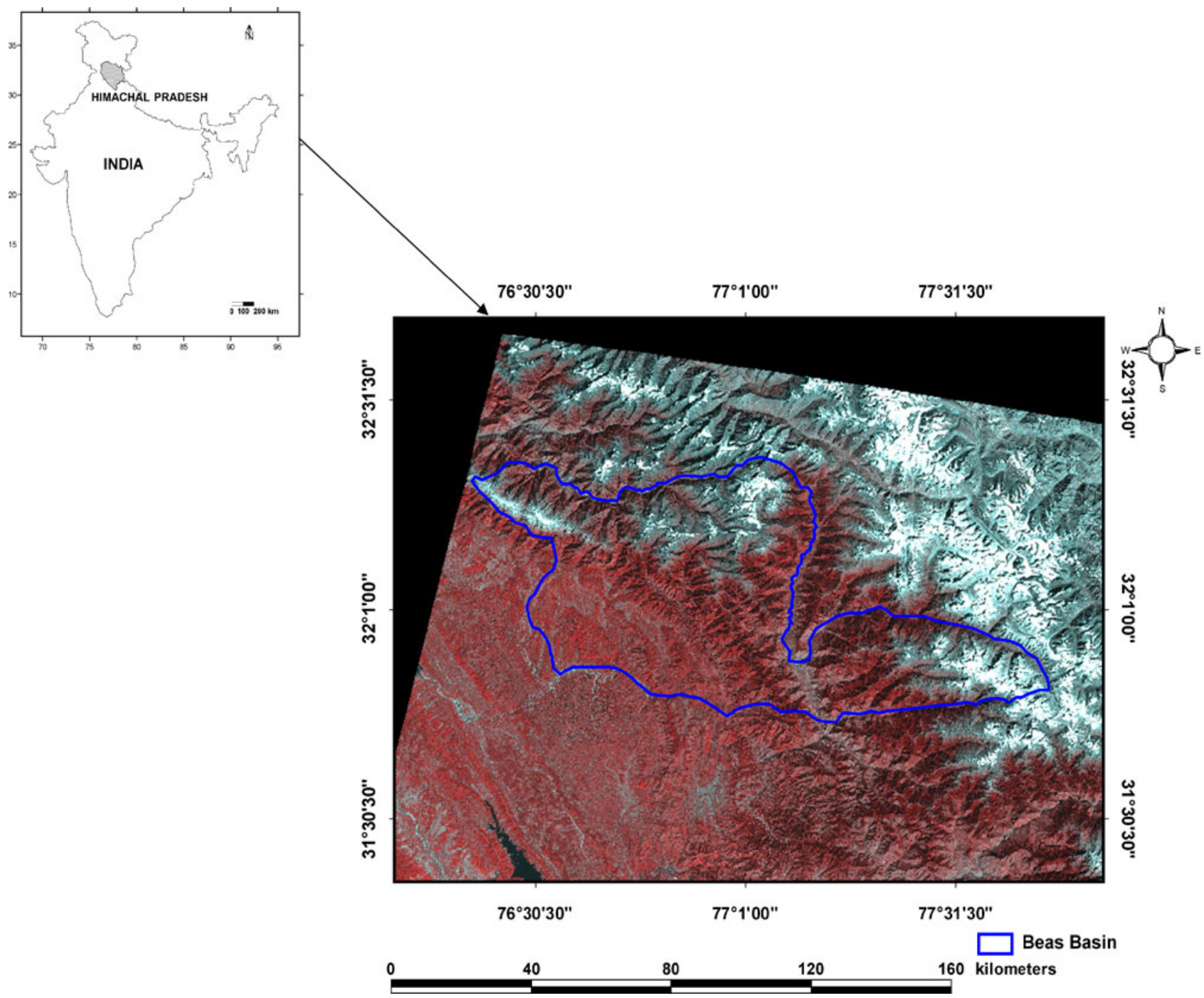

Figure 1. Area of study illustrating Beas River Basin in Himachal Pradesh (IRS LISS III 2001; modified after Kulkarni 1991). 
by GSI in the Parbati sub-basin $\left(>1 \mathrm{~km}^{2}\right)$. The present study is more comprehensive as it includes change detection of 169 glaciers $\left(>0.5 \mathrm{~km}^{2}\right)$ of the Parbati basin for a period of about three decades. Although Kulkarni et al. (2011) have monitored the snow cover in the Beas basin for the period 1997-2006; no study is reported on the deglaciation pattern for this fourth order glacier basin of Indus. In this investigation, an attempt has been made to estimate the extent and pattern of deglaciation during the period 1972-2006 using the sequential temporal images covering the entire Beas basin (including the Parbati sub-basin) of the Himachal Pradesh.

\section{Area of study}

The Beas basin identified as IN 5Q221 according to the UNESCO/TTS number is a fourth order river basin of Indus, bounded between latitude $31^{\circ} 31^{\prime} 00^{\prime \prime}-32^{\circ} 45^{\prime} 00^{\prime \prime} \mathrm{N}$ and longitude $76^{\circ} 44^{\prime} 00^{\prime \prime}-$ $77^{\circ} 52^{\prime} 00^{\prime \prime} \mathrm{E}$ (figure 1). The area is delineated by the water divide of Beas/Satluj in the east and south, Ravi/Beas in the north and Chenab in the north and northeast while Punjab plains lie in the west. Beas is an important river of the Indus river system. It originates in the Beas Rikhi at the Rohtang Pass in Himachal Pradesh and flows in almost north-south direction. At Larji, it takes a sharp turn towards the southwest up to Pandoh Dam. It joins river Satluj at Harike Pattan, in Ferozpur district of Punjab. Its major glacier fed tributaries are Parbati and Sainj Khad rivers. The Parbati river flows towards west and joins Beas at Bhuntar. The catchment area is largely comprised of precipitous slopes and bare rocks. The highest elevation lies at $6632 \mathrm{~m}$ asl on Parbati/Chenab divide (Sangewar and Shukla 2009).

\section{Methodology}

\subsection{Data source}

The investigations were carried out using Landsat (Multi Spectral Scanner MSS, Thematic Mapper
TM and Enhanced Thematic Mapper ETM+) images of 1972, 1989, 2001 and Indian Remote Sensing Satellite (IRS) images of 2001 and 2006 (table 1) for mapping the glaciated terrains in the Beas basin. The satellite images incorporated in the present study differ in spatial resolution, ground swath, and number of bands (table 1). The variation can be attributed to the availability of satellite images during the chosen study period and the subsequent advancement with time. This can also limit its accuracy. Nevertheless, moving on from low resolution to high resolution gives way for a more accurate interpretation. The 2000 SRTM image was used to generate contours in the entire basin. These are the most readily available source of remote sensing-derived elevation data over the Himalaya.

\subsection{Rectification of satellite data}

The IRS images were rectified using ground control points of known geographical identifiers through the DGPS survey (Spectra Precision EPOCH 10). Field verification was carried out in the glaciers of adjacent basin, viz., Chhota Shigri glacier (Chandra basin), Panchnala glacier (Bhaga basin) and Patsio glacier (Bhaga basin). The ground data was then validated with the satellite image and the subset for the Beas basin was extracted from the LISS III image. The IRS LISS III 2001 image was considered as the Master image and the other images were georeferenced with respect to it. Because of the different resolutions for different datasets, the image co-registration was done carefully. These data were registered and resampled to 24 pixel size to keep the uniformity in dataset. The projection and datum in this study was assigned as Geographic Lat./Long. and WGS 84, respectively.

\subsection{Glacier mapping}

The mapping of the glacier in the Beas basin was carried out by manual digitization because the

Table 1. Details of satellite data used in the analysis.

\begin{tabular}{llccc}
\hline Year & Sensor & $\begin{array}{c}\text { Spatial } \\
\text { resolution }(\mathrm{m})\end{array}$ & Date of acquisition & $\begin{array}{c}\text { Ground } \\
\text { swath (km) }\end{array}$ \\
\hline 2006 & IRS 1-C LISS III & 23.5 & 15 August 2006 & 141 \\
2001 & IRS 1-C LISS III & 23.5 & 15 September 2001 & 141 \\
2001 & Landsat ETM+Panchromatic & 15 & 15 October 2001 & 185 \\
1989 & Landsat ETM+ Multispectral & 30 & 9 October 1989 & 185 \\
1972 & Landsat TM & 30 & 11 November 1972 & 185 \\
\hline
\end{tabular}


debris-covered ice and the surrounding bedrock exhibit a similar spectral reflectance in automated classification (Andreassen et al. 2008; Bolch et al. 2010). The identification of snout and various glacio-morphological features around the glacier such as stream, lateral/medial/terminal moraines, and cliffs were used as a tool to delineate the glacial boundaries. Various algorithms such as addition, subtraction and band ratioing were applied on the image to enhance glacial features. Debris cover and glacial ice was differentiated by the false colour composite of bands and ratioing TM4/TM5 (Bhambri and Bolch 2009) and the application of addition algorithms gave more clarity in identification of peaks. Necessary precautions and utmost care were taken for an error free visual interpretation.

The glacier boundaries on the satellite images were mapped using PCI Geomatica 9.1 software on 1:50,000 scale using the standard combination of near-infra red, green and red bands and natural colour composite of blue, green and red bands. Image enhancement technique was used to enhance the difference between glaciated and non-glaciated areas. With these techniques, glacier inventory data sheet showing parameters (area, length, perimeter, elevation) for each glacier in the basin for the period 1972, 1989, 2001 and 2006 was generated in the GIS environment using Arc View 3.2. The areal change for the entire basin was then estimated by a comparative study of glaciated cover on a decadal basis during the period 1972 and 2006. We divided the glaciers into four classes, viz., $0.5-2,2-5,5-10$ and $>10 \mathrm{~km}^{2}$ (table 2 ) and the ice/snow bodies with an area $<0.5 \mathrm{~km}^{2}$ were not considered as glaciers (Post et al. 1971; Granshaw 2001; Kulkarni et al. 2007). The broader range of categorization facilitated a better picture for a correlation between spatial and temporal attributes.

\subsection{Error assessment}

The error in mapping of the glaciated area in the basin was validated from the 'Inventory of the Himalayan Glaciers' published by GSI (Sangewar and Shukla 2009) and Negi et al. (2009).

\section{Results}

The study focuses on the extent of deglaciation in the Beas basin through sequential temporal images of 1972, 1989, 2001 and 2006 (table 2). The investigation reveals that the total glaciated area of the basin in 1972 was $419.9 \mathrm{~km}^{2}$ which reduced to $398.2 \mathrm{~km}^{2}$ in $1989,372.36 \mathrm{~km}^{2}$ in 2001 and $371.23 \mathrm{~km}^{2}$ in the year 2006. Therefore, the Beas basin witnessed a deglaciation of about $48.77 \mathrm{~km}^{2}$ during 1972-2006 (table 2) which is about $11.6 \%$ of the glaciated area occupied in 1972. The above data also illustrates that the basin lost about 5.2\% of its glaciated area during 1972-1989 and about $6.78 \%$ during 1989-2006 (table 2). Thus the rate of retreat has increased during 1989-2006. It is noteworthy that the comparative temporal analysis carried out in both these time intervals depicts a difference of 17 years. A comparison of areal change between the period 2001 and 2006 was not included because the comparison does not show any significant results.

The glaciers in the basins were categorized into four classes based on their area. Glaciers in various categories behaved in diverse trends throughout the basin. Figure 2 illustrates a detailed insight of deglaciation in the Beas basin as analysed in various areal extents. The results show that the glaciers between 2 and $5 \mathrm{~km}^{2}$ have witnessed about $29 \%$ deglaciation which is highest amongst all areal categories (table 2). Glaciers with area more than $5 \mathrm{~km}^{2}$ and less than $2 \mathrm{~km}^{2}$ showed less variation reflecting not much of significant loss.

Another important aspect in the present investigation was an estimation of the total number of glaciers present in the basin and their temporal variation. The basin shows an increase in the number of glaciers from 224 in 1972 to 236 in 2006 . Figure 3 illustrates a comparative account of the fluctuation in the number of glaciers with respect to various categories of area and reveals that the glaciers in the range $0.5-2 \mathrm{~km}^{2}$ showed a higher tendency towards fragmentation.

A range of contour datasets including the minimum and maximum elevation of ablation and accumulation areas was generated for the entire basin with the help of SRTM image and the mean elevation of the ablation as well as accumulation area

Table 2. Extent and pattern of deglaciation in the Beas basin during 1972-2006.

\begin{tabular}{|c|c|c|c|c|c|c|}
\hline \multirow[b]{2}{*}{ Period of study } & \multirow{2}{*}{$\begin{array}{c}\text { Area vacated } \\
\qquad\left(\mathrm{km}^{2}\right)\end{array}$} & \multirow{2}{*}{$\begin{array}{c}\text { Area vacated } \\
(\%)\end{array}$} & \multicolumn{4}{|c|}{ Area of glaciers $\left(\mathrm{km}^{2}\right)$} \\
\hline & & & $(0.5-2)$ & $(2-5)$ & $(5-10)$ & $>10$ \\
\hline 1972-1989 & 21.7 & 5.2 & -11.38 & 23 & -2.81 & 23.18 \\
\hline 1989-2006 & 27 & 6.78 & -2.06 & 7.71 & 22.73 & 19.57 \\
\hline $1972-2006$ & 48.7 & 11.6 & -13.4 & 28.9 & 20.22 & 38.54 \\
\hline
\end{tabular}



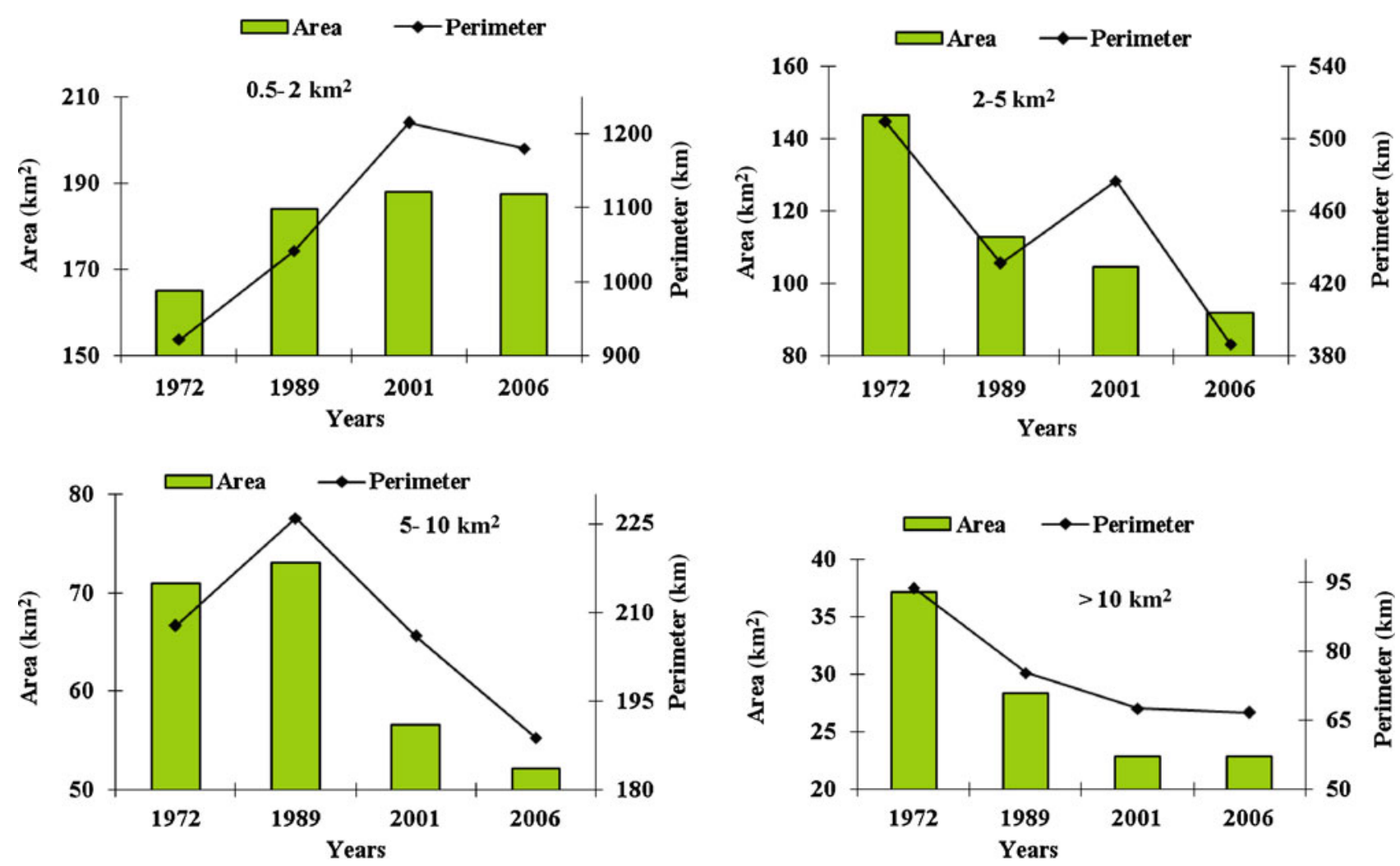

Figure 2. Graphical representation of the deglaciation pattern in the Beas basin during 1972-2006.

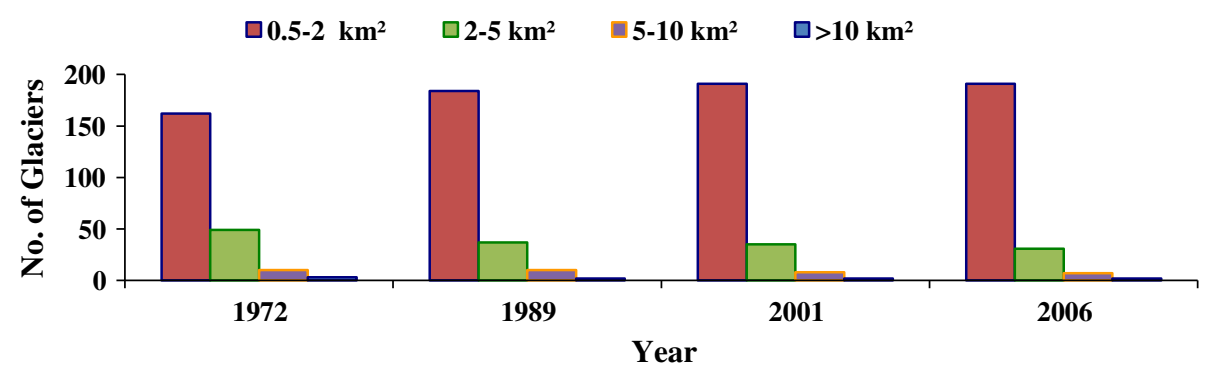

Figure 3. A comparative account of the fluctuation in the number of glaciers with respect to various categories of area.

Table 3. An account of variation in average elevation range in the period 1972-2006.

\begin{tabular}{cccc}
\hline & $\begin{array}{c}\text { Mean elevation of } \\
\text { the accumulation } \\
\text { area of the basin }(\mathrm{m})\end{array}$ & $\begin{array}{c}\text { Mean elevation of } \\
\text { the ablation area } \\
\text { of the basin }(\mathrm{m})\end{array}$ & $\begin{array}{c}\text { Average elevation } \\
\text { of the basin } \\
(\mathrm{m})\end{array}$ \\
\hline 1972 & 5073 & 3898 & 4486 \\
1989 & 5120 & 3869 & 4495 \\
2001 & 5185 & 4021 & 4603 \\
2006 & 5188 & 4171 & 4680 \\
\hline
\end{tabular}

was computed. The average elevation value for the ablation area was estimated to be $3898,3869,4021$ and $4171 \mathrm{~m}$ for the year 1972, 1989, 2001 and 2006, respectively (table 3 ).
Negi et al. (2009) have reported the glaciated area of the basin as $347 \mathrm{~km}^{2}$. The results of this study were compared with this work and it gives an error of $\pm 6.46 \%$ (figure 4 ). 


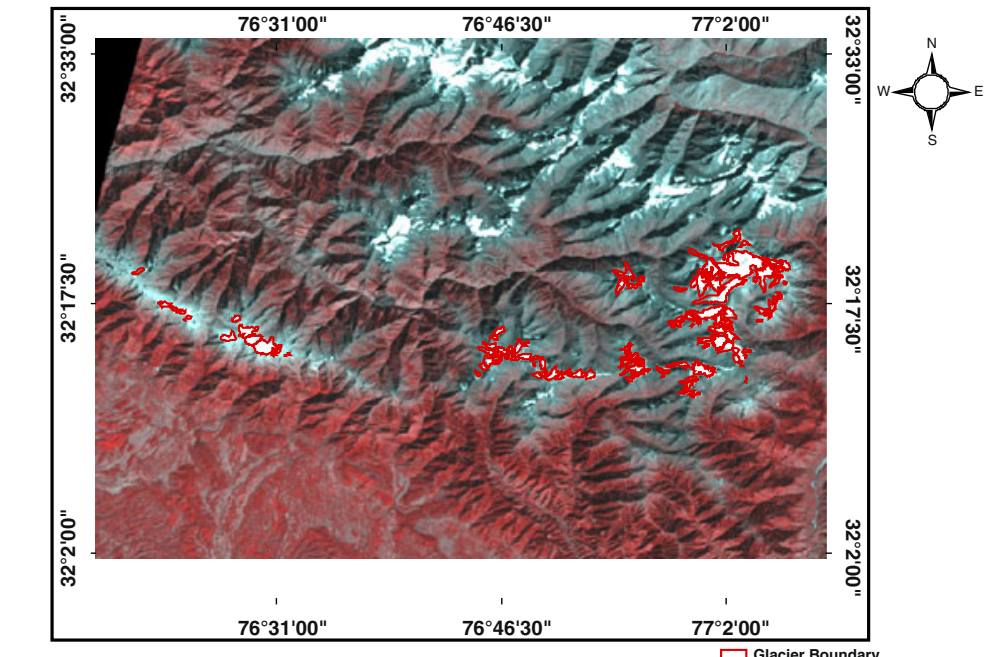

(a)
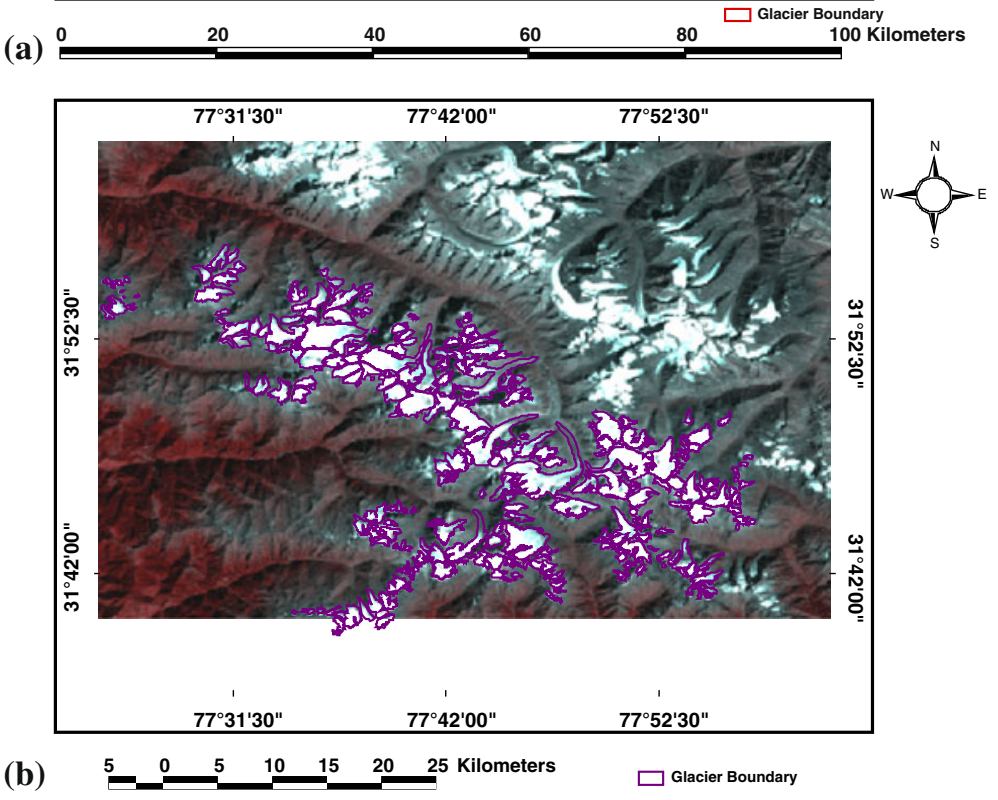

Figure 4. Glacier mapping in the Beas basin on the Landsat Image 2001. (a) Beas basin excluding the Parbati sub-basin and (b) Parbati sub-basin.

\section{Discussion}

The glaciers in the Beas basin have shown a recession with an area loss of about $11.6 \%$ in a period of three decades. Various studies based on a continuous monitoring of the mean annual temperature of the Northern Hemisphere indicate a significant warming up to 1940 , cooling up to the late sixties and renewed warming after 1970 (Mitchell 1963; Angell and Korshover 1978; Hansen et al. 1981; Jones et al. 1982). Trend analyses of the maximum, minimum and mean temperatures in the northwestern Himalayan region during 1901-2002 (Bhutiyani et al. 2007) reveal that there has been a rise by $1.6^{\circ} \mathrm{C}$ in the air temperature over the region and the warming rate has been highest during 1991-2002. Dash et al. (2007) have suggested that there has been a rise of $0.9^{\circ} \mathrm{C}$ of annual maximum temperature over the west- ern Himalaya. A recent study by Shekhar et al. (2010) reveals that the seasonal mean temperature for the period 1984-1985 to 2007-2008 in the western Himalaya has increased by $\sim 2^{\circ} \mathrm{C}$. A rise in air temperature serves as an indicator to change in climate and this change is manifested in the regional climate. Therefore it can be said that there has been a warming trend in western Himalaya. Subsequently, the impact of climate change is primarily reflected in the micro-climate of the region and glaciers serve as an excellent terrestral indicator for climate change. Another significant aspect of this study was the larger area vacated during the period 1989-2006 as compared to the loss during 1972-1989 in the Beas basin. A recent study in the Garhwal Himalaya also validates this finding where a higher rate of retreat has been reported during 1990-2006 (Bhambri et al. 2011). Bhutiyani et al. (2007) also indicate that 
the warming rate has been highest during 19912002.

The most extensive retreat has been observed in the glaciers with an areal extent of $2-5 \mathrm{~km}^{2}$. The response time of glaciers has been defined as the time taken to adjust to change in its mass balance. Previous research has shown that the glacier response time is directly proportional to thickness (Johannesson et al. 1989) which in turn depends upon the areal extent (Chaohai and Sharma 1988). Therefore, smaller glaciers are expected to be more prone to climatic changes. Subsequently, the most extensive retreat has been observed in the glaciers with areal extent of $2-5 \mathrm{~km}^{2}$ in this investigation also. These glaciers are under bigger threat as compared to the larger glaciers. A previous work (Kulkarni et al. 2007) also confirms this observation.

The upward shift of the contours, or in other words, glacier thinning and retreat over a period of three decades is noteworthy. The altitude controls important glaciological activities such as period of incoming solar radiation in a narrow valley (Wagnon et al. 2007), the ablation and accumulation. So, any change in the altitudinal range might be an indication of a modification in the terrain characteristics and dynamics. The gradual upward shifting of contours over a period of almost four decades can be a consequence of a shift in Equilibrium Line Altitude (ELA) which has been constantly moving upwards showing a retreat of glaciers in the region. Moreover, it is also indicative of a negative mass balance. The altitudinal variation in the ablation area over a period of time from $4486 \mathrm{~m}$ (1972) to $4680 \mathrm{~m}$ (2006) bears resemblances to previous reported works. Sangewar and Shukla (2009) have reported the altitudinal range between 4600 and $4900 \mathrm{~m}$ whereas Negi et al. (2009) suggest the average altitude of this region between 2000 and $4000 \mathrm{~m}$.

Therefore, the present investigation of the deglaciation pattern in the Beas basin during 1972-2006 suggests that small glaciers show more sensitivity towards retreat whereas larger glaciers are getting fragmented. The pace of retreat has accelerated in recent times. The intimate linkages of glaciers with the hydro power resources and its significance for the economic importance in agricultural purposes cannot be ignored. A systematic, continuous and detailed monitoring should be carry forwarded to assess the pattern of fluctuation in the coming decades and its linkages with the availability of water resources.

\section{Acknowledgements}

The authors are thankful to Space Application Centre, ISRO, Ahmedabad for providing the satellite imageries of 2001 and 2006.

\section{References}

Andreassen L M, Paul F, Kääb A and Hausberg J E 2008 The new Landsat-derived glacier inventory for Jotunheimen, Norway, and deduced glacier changes since the 1930s; The Cryosphere 2(2) 131-145.

Angell J K and Korshover J 1978 Global temperature variation, surface-100 mb: An update into 1977; Mon. Weather Rev. 106 755-770.

Berthier E, Arnaud Y, Kumar R, Ahmad S, Wagnon P and Chevallier P 2007 Remote sensing estimates of glacier mass balances in the Himachal Pradesh (Western Himalaya, India); Remote Sens. Environ. 108 327-338.

Bhambri R and Bolch T 2009 Glacier mapping: A review with special reference to the Indian Himalayas; Prog. Phys. Geog. 33(5) 672-704.

Bhambri R, Bolch T, Chaujar R K and Kulshreshtha S C 2011 Glacier changes in the Garhwal Himalaya, India, from 1968 to 2006 based on remote sensing; J. Glaciol. 57(203) 543-556.

Bhutiyani M R, Kale V S and Pawar N J 2007 Longterm trends in maximum, minimum and mean annual air temperatures across the northwestern Himalaya during the twentieth century; Climatic Change 85(1-2) 159-177.

Bhutiyani M R, Kale V S and Pawar N J 2009 Climate change and the precipitation variations in the northwestern Himalaya: 1866-2006; Int. J. Climatol. 30(4) $535-548$.

Bolch T, Menounos B and Wheate R 2010 Landsat-based inventory of glaciers in western Canada, 1985-2005; Remote Sens. Environ. 114 127-137.

Chaohai L and Sharma C K 1988 Report on first expedition to glaciers in the Pumqu (Arun) and Poiqu (Bhote-Sun Kosi) river basins, Xizang (Tibet), China, Science Press, Beijing, p. 192.

Dash S K, Jenamani R K, Kalsi S R and Panda S K 2007 Some evidence of climate change in twentieth-century India; Climatic Change 85(3-4) 299-321.

Granshaw F D 2001 Glacier change in the north Cascades National Park Complex, Washington State, USA, 1958 to 1998; Thesis submitted for the Master of Science in Geology, Portland State University, 2002.

Hansen J, Johnson D, Lacis A, Lebedeff S, Lee E, Rind D and Russel G 1981 Climate impact of increasing atmospheric carbon dioxide; Science 213 957-966.

Immerzeel $\mathrm{W}$ W, van Beeke $\mathrm{L} \mathrm{P} \mathrm{H}$ and Bierkens $\mathrm{M} \mathrm{F} \mathrm{P}$ 2010 Climate change will affect the Asian water towers; Science 328 1382-1385.

IPCC 2007 Climate Change 2007: The Physical Scientic Basis; In: Contribution of Working Group I to the Fourth Assessment Report of the IPCC (eds) Solomon S, Qin D, Manning M, Chen Z, Marquis M, Averyt K B, Tignor M and Miller H L (Cambridge, UK: Cambridge University Press), 996p.

Johannesson T, Raymond C F and Waddington E D 1989 Timescale for adjustment of glaciers to changes in mass balance; J. Glaciol. 35 355-369.

Jones P D, Wigley T M L and Kelly P M 1982 Variations in surface air temperatures: Part 1. Northern Hemisphere 1881-1980; Mon. Weather Rev. 110 59-70.

Kulkarni A V 1991 Glacier inventory in Himachal Pradesh using satellite data; J. Indian Soc. Remote Sens. 19(3) 195-203.

Kulkarni A V, Rathore B P, Mahajan S and Mathur P 2005 Alarming retreat of Parbati glacier, Beas basin, Himachal Pradesh; Curr. Sci. 88(11) 1844-1850.

Kulkarni A V, Bahuguna I M, Rathore B P, Singh S K, Randhawa S S, Sood R K and Dhar S 2007 Glacial retreat 
in Himalaya using Indian remote sensing satellite data; Curr. Sci. 92(1) 69-74.

Kulkarni A V, Rathore B P, Singh S K and Bahuguna I M 2011 Understanding changes in the Himalayan cryosphere using remote sensing techniques; Int. J. Remote Sens. 32(3) 601-615.

Mehta M, Dobhal D P and Bisht M P S 2011 Change of Tipra Glacier in the Garhwal Himalaya, India, between 1962 and 2008; Prog. Phys. Geog. 35 721-738.

Mitchell J M 1963 On the World-Wide Pattern of Secular Temperature Change; Proceedings of UNESCO/WMO Symposium on Changes of Climate, UNESCO Arid Zone Research Series 20 161-181.

Negi H S, Kulkarni A V and Semwal B S 2009 Estimation of snow cover distribution in Beas basin, Indian Himalaya using satellite data and ground measurements; J. Earth Syst. Sci. 118(5) 525-538.

Post A, Richardson D, Tangborn W V and Rosselot F L 1971 Inventory of Glaciers in the North Cascades Washington; US Geological Survey, Professional Paper 705-A 19.
Prasad V H and Roy P S 2005 Estimation of snowmelt runoff in Beas Basin, India; Geocarto International 20(2) $41-47$.

Raina V K and Srivastava D 2008 Glacier atlas of India; Bangalore Geological Society of India, 316p.

Sangewar C V and Shukla S P 2009 Inventory of the Himalayan Glaciers; Spec. Publ. No. 34, Geological Survey of India.

Shekhar M S, Chand H, Kumar S, Srinivasan K and Ganju A 2010 Climate-change studies in the western Himalaya; Ann. Glaciol. 51(54) 105-112.

Technical report on snow and glaciers of Himalaya 2011 SAC, ISRO, Ahmedabad, India, report no. SAC/RESA/MESA/SGP/TR/59/2011.

Wagnon P, Linda A, Arnaud Y, Kumar R, Sharma P, Vincent C, Pottakkal J G, Berthier E, Ramanathan A L, Hasnain S I and Chevallier P 2007 Four years of mass balance on Chhota Shigri Glacier, Himachal Pradesh, India, A New Benchmark Glacier in the Western Himalaya; J. Glaciol. 53(183) 603-611. 